\title{
Sciendo
}

Acta Veterinaria-Beograd 2020, 70 (4), 423-434

Research article

UDK: 636.1.09:616.728-001

DOI: 10.2478 /acve-2020-0032

\section{RISK FACTORS FOR THE OCCURRENCE OF \\ DESMOPATHY OF THE COLLATERAL LIGAMENTS OF THE DISTAL INTERPHALANGEAL JOINT IN EQUINES - A CROSS-SECTIONAL STUDY}

\author{
GÓSS Geórgia Camargo*, MOZZAQUATRO Fabricio Desconsi, MACHADO Ingrid \\ Rios Lima, GOMES Etiele Maldonado, DA SILVA Graziele Salgueiro, CARNEIRO \\ Ana Luisa Moreira, SILVEIRA Bruno Belmonte, RIVERO Bruno Afonso, DUARTE \\ Claudia Acosta
}

UNIPAMPA, BR 472, Km 585, CEP 97501-970, Uruguaiana, RS

(Received 02 February, Accepted 16 October 2020)

\begin{abstract}
Desmopathy of the collateral ligaments of the distal interphalangeal joint (CL-DIPJ) has been increasingly relevant in equine sports medicine. However, the risk factors for the development of such desmopathy are not well established. In the literature, what has been described about it, is based on the clinical conditions observed in animals diagnosed with this disorder. Considering this scenario, the aim of this study was to verify which possible extrinsic or intrinsic risk factors may influence the occurrence of disorders in the collateral ligaments of the distal interphalangeal joint in polo horses. Twenty-five horses from the same equestrian team, all competing in polo, were evaluated via ultrasonography. The outcome was defined as changes in echogenicity and/or boundaries of the CL-DIPJ of the thoracic limbs of the horses evaluated. The intrinsic factors considered in this study were age, the presence of angular deviations and gender. As extrinsic factors, the parameters taken into consideration were the handicap in which the animals played and the type of training to which these horses were previously submitted in their professional athletic career. The prevalence ratio was used to verify the association between risk factor and outcome. The result of this evaluation was considered significant when the confidence interval value did not involve the value 1 . Positive and significant association was observed only for age. Playing in different handicaps did not influence the presence of ligament disorders. The other factors evaluated revealed a positive but not significant association. Thus, it was concluded that animals aged nine years or older present a higher risk of CL-DIPJ disorders.
\end{abstract}

Key words: angular deviation; age; predisposition; polo; sex

*Corresponding author: e-mail: georgia_goss@hotmail.com 


\section{INTRODUCTION}

Collateral ligaments of the distal interphalangeal joint (CL-DIPJ) of horses are one of the most affected structures in the hoof region, being the second most disturbed [1]. These lesions occur due to biomechanical stress caused by distal phalanx collateromotion movements at the moment of hoof support on the ground. These movements, when exacerbated, may lead to CL-DIPJ desmitis [2].

The probable risk factors for the occurrence of this condition are based on the common clinical findings in the affected animals. Dyson et al. [3] reinforce the need for studies that aid to establish them. Denoix et al. [4] verified in all the reported cases of CL-DIPJ desmitis the presence of chronic medial-lateral hoof imbalance, which was also pointed out by Zubrod et al. [5]. The results of the study of Zubrod et al. [5], also suggest that angular deformities could predispose their occurrence, since this feature was observed concomitantly with the manifestation of desmitis. Previously in a series of 18 cases described by Dyson et al. [3], it was noted that the affected animals had an average age of nine years (5-14 years) and practiced different sports. The practice of equestrian sports that consist of performing circular movements in conjunction with sudden stops and exercises on uneven ground lead to irregular support of the hoof, is also considered a cause of desmitis in these structures [2,5].

Epidemiological studies have been conducted in order to seek and clarify what influences the occurrence of skeletal muscle injuries in equine athletes. Although much has already been done, none of these targeted CL-DIPJ. Risk factors for changes in the hoof region were assessed by Parkes et al. [6], who verified that the lesions of the podotrochlear apparatus of the studied population were influenced by the increase of age and gender. Many authors have also explored for which intrinsic and/or extrinsic characteristics predispose to flexor tendons and suspensory apparatus (SA) lesions. Thus, it was found that, for these structures, increased age [7-10] and animal gender [9] predispose to the occurrence of lesions. In addition, studies regarding the distal limb conformation show the relationship between the presence of angular deviations and the occurrence of flexor tendon changes [11], as well as their influence on their athletic career [12,13].

Considering the relevance of the CL-DIPJ and the lack of information about which risk factors influence the ligament injury process, the aim of this study was to verify which possible extrinsic or intrinsic risk factors may influence the occurrence of collateral ligament disorders in the distal interphalangeal joint of polo horses.

\section{MATERIALS AND METHODS}

\section{Ethics Commission}

The experiment was carried out under Project License from the Ethics Commission of the Federal University of Pampa, Uruguaiana, Brazil (process number 027/2017). 


\section{Study population}

Twenty-five polo horses were used, with average age of $8 \pm 3$ years, height of $1.53 \pm$ $0.4 \mathrm{~m}$ and weight of $470 \pm 28.67 \mathrm{~kg}$, being 7 geldings and 18 females. All were in polo season and came from the same property. Thus, food and sanitary management, hoof care, training program and floor type were equal in the population studied.

\section{Intrinsic Risk Factors}

The intrinsic factors evaluated were age, gender, presence of angular deviations and medial lateral hoof imbalance. Age was verified by birth registration and horses were divided between animals under nine years old and horses nine years old or older. Sex was defined by external observation of the genitals, being divided into females and geldings.

The presence of angular deviations was defined by inspection of the horses in quadrupedal position on a straight floor. The evaluator observed the animals in a frontal view, looking for deviations of the thoracic limbs. Whenever there was, it was considered to have valgus or varus angular deviation.

The medial-lateral imbalance of the hoof was verified by measuring the height of the lateral and medial heels. It was considered unbalanced a hoof in which the difference in height of the heels was equal to or greater than $0.5 \mathrm{~cm}$.

\section{Extrinsic Risk Factors}

For this study, extrinsic factors as the handicap and training prior to professional athletic career were considered. The handicap in which they played was reported by the veterinarian responsible for the property and was divided between those who played high and low handicap.

To define the training that preceded the professional athletic career, the horses were divided between those born on the property or purchased. Those who were born on the property were tamed at three years of age, underwent an evaluation of their athletic performance between four and six years and, at six years of age, having reached the desired level of exercise, started professional sports activity. Purchased animals were obtained in adulthood, so there was no information on previous training.

\section{Outcome Definition}

Ultrasound evaluation of CL-DIPJ was performed on the thoracic limbs of all horses according to the previously described technique [14]. Those with alterations in echogenicity and/or boundaries in at least one of the ligaments were considered affected. 


\section{Clinical assessment of horses}

All horses evaluated underwent a general and specific physical examination of the locomotor system. For this, dehydration level and body temperature were considered, heart and respiratory rates were measured, and auscultation of intestinal motility was performed.

For the specific examination of the locomotor system, static inspection was first performed in order to investigate possible increases in volume in the region of the ligaments. In sequence, the dynamic evaluation was performed, with the animals being evaluated at walk and trot. In addition, the veterinarian responsible for the animals was also consulted in an attempt to identify possible previous lameness in the digit region.

\section{Data analysis}

Data analysis was performed using software (CEMEQ - USP) in which the prevalence ratio was calculated. The number of individuals was used for age, handicap and previous training factors. For the presence of angular deviations and hoof imbalances factors, the number of thoracic limbs was used.

When PR $=1$, it was considered that there was no association between the factor and the occurrence of ligament disorder. When greater than 1, it was interpreted as a positive association between the presence of the factor and the occurrence of disorder. Also, if $\mathrm{PR}<1$, it was considered as a protection factor. Thus, the higher the prevalence ratio, the stronger the association was considered. Even if PR $>1$ was observed, the association between factor and outcome was only considered statistically relevant when the confidence interval did not involve value 1 .

\section{RESULTS}

In the present study, $40 \%(10 / 25)$ of the horses had echogenicity and/or boundaries changes observed by ultrasonography on CL-DIPJ. Of these 10 horses, 50\% (5/10) had sonographic changes in the lateral and medial collateral ligaments of the same thoracic limb - 20\% (1/5) in the right thoracic limb (RTL) and 80\% (4/5) in the left thoracic limb (LTL), 30\% (3/10) presented changes in only one collateral ligament, both in the LTL- 75\% (2/3) in the medial collateral ligament and 25\% (13) in the lateral collateral ligament. Of the remaining 2 horses, $50 \%(1 / 2)$ presented alterations in the medial collateral ligament of the RTL and the other one presented changes in the lateral collateral ligament of the RTL and in the medial collateral ligament of the LTL.

The frequencies of occurrence of these changes in the exposed and unexposed can be observed in Figure 1 for intrinsic factors and in Figure 2 for extrinsic factors. The factor of medial-lateral imbalance of the hoof was considered a bias factor and disregarded in this study. 


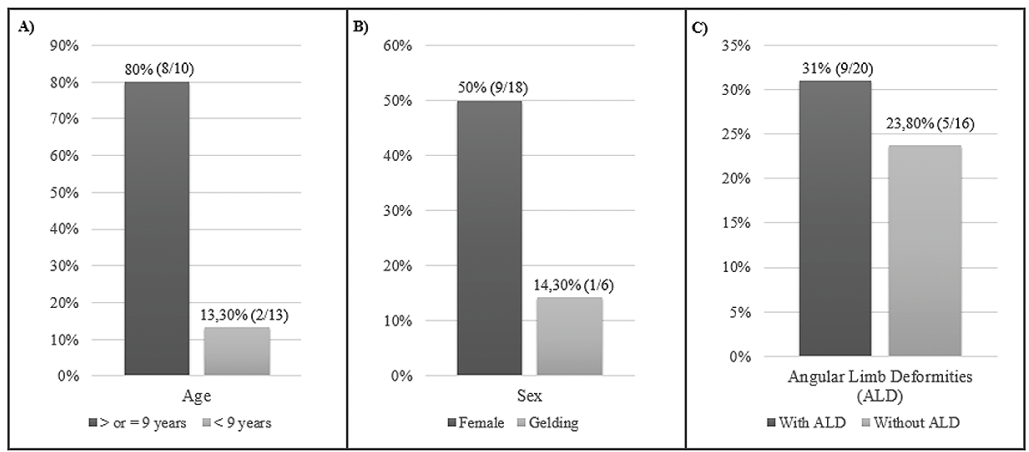

Figure 1. Graphs comparing the frequency of occurrence of collateral ligament of the distal interphalangeal joint disorders in horses submitted to the equestrian polo for the different intrinsic risk factors. A) Comparison of frequency of occurrence of ligament disorders between horses of different ages. B) Comparison of frequency of occurrence of ligament disorders between female and castrated male horses. C) Comparison of frequency of occurrence of ligament disorders between horses with and without angular deviations.

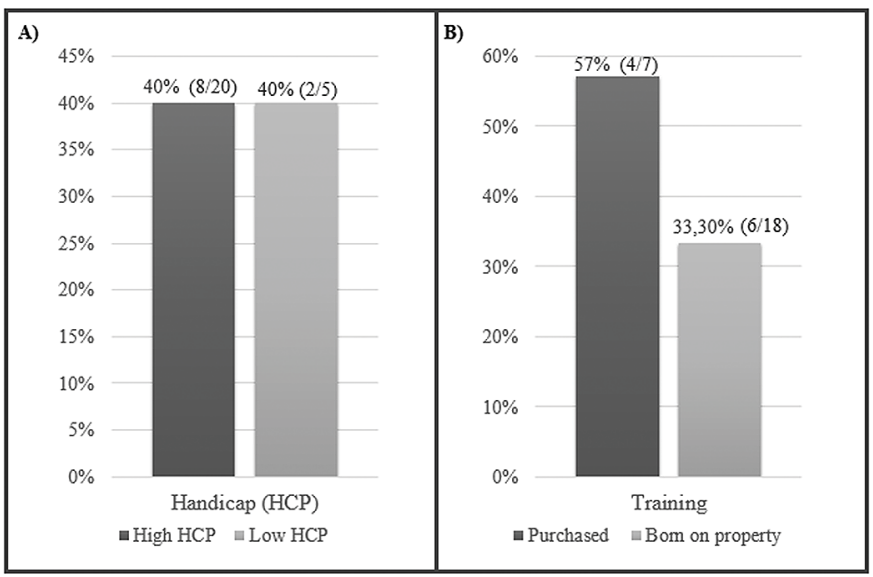

Figure 2. Comparative graphs of the frequency of occurrence of injuries in collateral ligament of the distal interphalangeal joint of horses submitted to the polo for the different extrinsic risk factors. A) Comparison of frequency of occurrence of ligament disorders between horses playing at high and low handicap. B) Comparison of frequency of occurrence of ligament disorders between horses bought and born on the property.

The calculation of the prevalence ratio showed that the handicap in which the animals played did not influence the occurrence of ligament changes. The other factors were positively associated, as shown in Table 1 . Age was the only factor that was statistically relevant, so that animals aged nine years and over are 500\% more probable to develop changes in CL- DIPJ when compared to younger ones. 
Table 1. Values of the prevalence ratio, predisposition percentage of exposed animals and confidence interval observed in argentine polo horses considering the age, sex, angular deviations, handicap and previous training factors.

\begin{tabular}{lccc}
\hline Risk factor & $\mathbf{P R}^{\mathbf{1}}$ & $\mathbf{\%}^{\mathbf{2}}$ & $\mathbf{I C}^{\mathbf{3}}$ \\
\hline Age $=$ ou $>$ years & 6 & 500 & 1,$59 ; 22,62$ \\
Females & 3,5 & 250 & 0,$54 ; 22,76$ \\
Angular limb deformities & 1,303 & 30,3 & 0,$51 ; 3,33$ \\
High handicap & 1 & 0 & 0,$3 ; 3,32$ \\
Purchased animals & 1,714 & 71,4 & 0,$69 ; 4,28$ \\
\hline
\end{tabular}

${ }^{1}$ Prevalence ratio; ${ }^{2}$ predisposition percentage of exposed horses; ${ }^{3}$ Confidence intervals

Regarding the gender, conformation and previous training factors, although having a positive association with the occurrence of injuries, the confidence interval values do not allow extrapolating these results to the general population. Also, it was noted that females are more predisposed, as well as those animals with angular deviations. Regarding to previous training, animals born on the property presented less possibility of presenting ligament disorders.

None of the horses evaluated showed lameness in the digit region at the time of the study, as well as a history of lameness from that region.

\section{DISCUSSION}

Biomechanical stress caused by exacerbated phalanx collateromotion movements is reported to cause CL-DIPJ desmitis [2]. However, it is unclear what situations the animals are exposed to and/or individual characteristics predispose them to occur. Zubrod et al. [5], suggested that the practice of sports involving stops and turns, as well as those practiced on uneven terrain, provide this type of biomechanical alteration. Polo is one of the equestrian modalities in which these types of movement are observed during games [15] and, despite this, no description of CL-DIPJ desmopathy was found in animals of this modality, only being reported in horses training, running [3] and jumping [3,16].

Thus, the frequency of CL-DIPJ injuries observed in this study is an important finding since no previous reports of its occurrence in polo horses were found. This finding becomes even more relevant if it is considered that all LC-AID can be equally affected in animals that practice this sport. So, the presence of changes in ultrasonography images and their distribution in this study, demonstrates that the collateral ligaments of the distal interphalangeal joint and its changes must be included as a differential diagnosis in polo horses. Particularly, in those with lameness in the digit region, one of the regions most affected by the practice of this sport, in which it is not always possible to reach a definitive diagnosis [17]. 
This was the first epidemiological study that sought to define risk factors for CL-DIPJ injuries. The risk factors chosen to be evaluated in the present study were based on conditions previously mentioned, but which had only been observed clinically and, therefore, could not be confirmed as risk factors [2,5]. Thus, the medial-lateral hoof imbalance [2,5] and angular deviations [5] were included because they were previously reported as a common characteristic in horses affected by the condition. Nevertheless, the medial-lateral hoof imbalances were disregarded as the horses were constantly trimmed and shod, having been shod about 15 days prior to evaluation. Thus, the analysis of this variable made it impossible to define whether such condition is chronic or not, being invalidated for this study.

In addition to characteristics previously observed in cases of CL-DIPJ desmitis, factors that were reported to predispose to other skeletal muscle injuries were also considered. Thus, it was also evaluated age [6-10], sex [6,9] and exercise level [8]. The inclusion of the type of training prior to the athletic career was due to the particular form that the observed property performs at the beginning of the horse's activities. Thus, the authors sought to observe whether these precautions were being appropriate.

The fact that the evaluated horses did not show lameness even with the presence of changes in ultrasonography, makes the findings of this study even more important. As mentioned, studies that suggest possible risk factors in used horses that already had apparent lameness [2,5], so that there is a certain limitation of knowledge of pre-clinical predisposing factors. This study allows veterinarians to have subsidies to include CLDIPJ as a potential injury site in athlete animals that fall into risk groups. Thus, clinical desmitis of these ligaments can be prevented, along with other degenerative changes common in athletic horses.

One of the main findings of this study was the greater predisposition of animals aged nine years or older. The average age observed in horses in a series of 18 cases of CLDIPJ desmitis was nine years, corroborating with this finding [1]. Increasing age was also found to be a predisposing factor for general skeletal muscle injuries [7,8], for superficial digital flexor tendon (SDFT) tendonitis of the thoracic limbs $[9,10]$ and injuries to the suspensory apparatus (SA) [9] in racehorses. Similarly, considering the podotrochlear apparatus of horses used for dressage, jumping, running, endurance and reining, it was observed that animals aged six to ten years are subject to the occurrence of disorders and the risk increased further between 10-15 years [6].

Nevertheless, and agreeing with Perkins et al. [9], it is necessary to define if age has a direct influence on the lesions or if the influence of other factors is manifested together with the increase of the same. Given this, it is not possible to say whether the greater occurrence of CL-DIPJ desmopathy is due to changes in the biomechanical and/or biochemical properties that occur in the ligament fibers in older animals or to the longer time of sport practice and, consequently, greater exposure to repetitive trauma and biomechanical stress. Studies involving ligament biopsy would be necessary 
to clarify this, which is not feasible in animals that are in the sporting season, as was the case of the population studied.

Regarding sexual predisposition, previous studies have found a greater predisposition of males to the occurrence of lesions in SFDT and SA [9]. Stallions also had a higher number of lesions that had lameness in the hoof region, especially in the deep digital flexor tendon [6]. Perkins et al. [9], suggest that this finding could be related to hormonal issues or the tendency of stallions to have less docile behavior during training [9]. In our study it was observed the opposite, females were $71.4 \%$ more likely to develop changes in CL-DIPJ than males, which may be explained by the higher number of females composing the polo team evaluated or may be the fact that the males in this study were castrated and the hormonal characteristics mentioned in previous studies were not manifested in them.

As regards angular deviations, their influence is questionable and may be related to the activity performed. The athletic career of dressage horses was not influenced by the presence of angular deviations [13], while such conformation defects may affect and decrease the sporting career of horses, as observed by Ducro et al. [13] on jumping horses. Fugazzola et al. [11] compared radiographic measurements of the distal region of the thoracic limbs of healthy horses and horses with a history of SDFT tendonitis but could not confirm whether this is a predictor parameter for these disorders. Still, they reinforced that the understanding about its influence on the occurrence of locomotor injuries should be better clarified.

However, angular deviations were pointed as an important predisposing factor for SFDT tendonitis in racehorses where those with angular deviations presented a higher occurrence of the disease when compared to well-groomed animals [12]. The results of the present study corroborate this statement because, although not statistically significant, horses with this characteristic were $30.3 \%$ more predisposed to changes in CL-DIPJ, and further studies are needed regarding this factor. In addition, it is suggested that horses subjected to the equestrian polo be negatively affected by the presence of this trait.

In the present study, no influence of the handicap where the animals played was observed on the occurrence of ultrasonographic changes of the CL-DIPJ. Exercise intensity was not relevant in relation to alterations of SFDT and SA in racehorses [9]. In contrast, even in racehorses, increased exercise intensity (increased distance traveled) promoted a higher risk of skeletal muscle injury [8]. The influence of exercise intensity may vary according to the anatomical structure and activity of the horse. Moreover, in sports such as running, it is easy to verify the intensity of the exercise objectively, while in the polo the change of handicap does not always mean greater intensity, corroborating the observations in this work.

Regarding previous training, purchased animals were more predisposed to ligament disorders. Unfortunately, there was no information on the type of training they had undergone, which makes it difficult to identify the characteristics of these animals 
that corroborate the increased occurrence of CL-DIPJ desmopathy. In relation to animals born on the property, they were started at about three years of age and had a lower predisposition to changes in CL-DIPJ. This differs from what was observed by Reardon et al. [10], in which those horses that ran for the first time at three years had a higher risk of developing SFDT tendonitis than those that starting at four years. It may be extrapolated that the fact that animals born on the property were included in a gradual training program may have reduced the predisposition to injury. However, further studies would be necessary to verify if this fact can be attributed to a genetic background, to skeletal muscle adaptation to exercise or to their association.

Regarding the limiting factors of this study, the authors believe that the number of animals should be considered. Nevertheless, it is noteworthy that a complete polo team was evaluated and that all animals were on the same property, received the same attention and trained polo under the same conditions. Thus, it was sought to obtain homogeneity of the studied population, so that the influence of the modality, the type of ground and the regularity of the exercise was excluded. These factors were pointed out by Parkes et al. [6] as limiting in their study that verified several risk factors in injuries of the podotrochlear apparatus in horses of different modalities.

Finally, the fact that some of the risk factors in this study were positively associated with the occurrence of alterations of CL-DIPJ without, however, having statistical significance. This can be attributed to the fact that the interaction between intrinsic and extrinsic factors can cause synergistic or antagonistic effects on the injury-forming mechanism [7]. In addition, it is important to emphasize that locomotor disorders are often multifactorial [6]. Unfortunately, it is not possible to verify the interaction between the variables evaluated in a cross-sectional study. Nevertheless, the present study represents an initial effort to clarify the risk factors associated with the occurrence of collateral ligament desmopathies of the distal interphalangeal joint. Thus, it was possible to verify the positive and significant association between increasing age and the presence of disorders. Although not significant, a positive association was also observed between the occurrence of alterations in ultrasonography and the presence of angular deviations, gender and the gradual initiation of exercise in these horses. Thus, further studies with a larger number of animals are suggested to confirm this association, as well as longitudinal studies that evaluate these factors in a long term.

\section{CONCLUSION}

Horses that practice polo are subject to changes in CL-DIPJ, and those who are nine years-old or older are more predisposed to these alterations.

\section{Acknowledgements}

To the veterinarian Marcelo Teixeira Napoleão, the Estância Itapitocai and the Maragata Polo Team for making available the animals used in this study. This study 
was financed in part by the Coordenação de Aperfeiçoamento de Pessoal de Nível Superior - Brasil (CAPES) - Finance Code 001.

\section{Authors' contributions}

GCG developed the design, collection and evaluation of the data and wrote the manuscript. FDM, CAD and IRLM guided the first author, developed the design and assisted in data collection and evaluation. ALMC, BBS and BAR participated in the collection of data evaluation. EMG participated in the design, data evaluation and review of the english language. All authors read and approved the final version of the manuscript.

\section{Declaration of conflicting interests}

The author(s) declared no potential conflicts of interest with respect to the research, authorship, and/or publication of this article.

\section{REFERENCES}

1. Dyson SJ, Murray R, Schramme MC: Lameness associated with foot pain: results of magnetic resonance imaging in 199 horses (January 2001-December 2003) and response to treatment. Equine Vet J 2005, 37(2):113-121.

2. Denoix JM: The collateral ligaments of the distal interphalangeal joint: Anatomy, roles and lesions. Hoofcare \& Lameness 1998, 70(1):29-32.

3. Dyson SJ, Murray R, Schramme M, Branch M: Collateral desmitis of the distal interphalangeal joint in 18 horses (2001-2002). Equine Vet J 2004, 36(2):160-166.

4. Denoix JM, Bertoni L, Heitzmann AG, Werpy N, Audigiè F: Ultrasonographic examination of the collateral ligaments of the distal interphalangeal joint in horses. Part B: Abnormal findings and lesions. Equine Vet Educ 2011, 23(12):616-625.

5. Zubrod CJ, Farnsworth KD, Tucker RL, Ragle CA: Injury of colateral ligaments of the distal interphalangeal joint diagnosed by magnetic resonance. Vet Radio Ultrasound 2005, 46(1):11-16.

6. Parkes RS, Newton JR, Dyson SJ: An investigation of risk factors for foot-related lameness in a United Kingdom referral population of horses. Vet J 2013, 196(1):218-225.

7. Mohammed HO, Hill T, Lowe J: Risk factors associated with injuries in Thoroughbred horses. Equine Vet J 1991, 23(6):445-448.

8. Bailey CJ, Reid SWJ, Hodgson DR, Suann CJ, Rose RJ: Risk factors associated with musculoskeletal injuries in Australian Thoroughbred racehorses. Prev Vet Med 1997, 32(1):47-55.

9. Perkins NR, Reid SWJ, Morris RS: Risk factors for injury to the superficial digital flexor tendon and suspensory apparatus in Thoroughbred horses in New Zealand. N Z Vet J 2005, 53(3):184-192. 
10. Reardon RJM, Boden LA, Mellor DJ, Love S, Newton JR, Stirk AJ, Parkin TDH: Risk factors for superficial digital flexor tendinopathy in Thoroughbred racehorses in steeplechase starts in the United Kingdom (2001-2009). Vet J 2013, 195(1):325-330.

11. Fugazzola MC, Lancioni I, Duran MC, Canonici F, Petrizzi L: Correlation Between the Conformation of the Distal Forelimb and Superficial Digital Flexor Tendon Lesions in Flat Racing Thoroughbreds. J Equine Vet Sci 2015, 35(1):264-270.

12. Weller R, Pfau T, Verheyen K, May SA, Wilson AM: The effect of conformation on orthopaedic health and performance in a cohort of National Hunt racehorses: preliminary results. Equine Vet J 2006, 38(7):622-627.

13. Ducro BJ, Gorissen B, Van Eldik P, Back W: Influence of foot conformation on duration of competitive life in a Dutch Warmblood horse population. Equine Vet J 2009, 4192):144148.

14. Denoix JM, Bertoni L, Heitzmann AG, Werpy N, Audigiè F: Ultrasonographic examination of the collateral ligaments of the distal interphalangeal joint in horses: Part A: Technique and normal images. Equine Vet Educ 2011, 23(12):574-580.

15. Pfau T, Parkes RS, Burden ER, Bell N, Fairhurst H, Witte TH: Movement asymmetry in working polo horses. Equine Vet J 2016, 48(4):517-522.

16. Troppe GD, Whitton RC: Medial colateral ligament desmitis of the distal interphalangeal joint in the hindlimb of a horse: treatment with cast immobilisation. Aust Vet J 2009, 87(12):499-502.

17. De Souza NR, Luna SPL, Pizzigatti D, Martins MTA, Possebon FS, Aguiar ACS: Relation between type and local of orthopedic injuries with physical activity in horses. Ciênc Rural 2017, 47(2):1-7.

\section{FAKTORI RIZIKA ZA POJAVU DEZMOPATIJE KOLATERALNIH LIGAMENATA DISTALNIH INTERFALANGEALNIH VEZA KOD KONJA - UNAKRSNA STUDIJA}

GÓSS Geórgia Camargo, MOZZAQUATRO Fabricio Desconsi, MACHADO Ingrid Rios Lima, GOMES Etiele Maldonado, DA SILVA Graziele Salgueiro, CARNEIRO Ana Luisa Moreira, SILVEIRA Bruno Belmonte, RIVERO Bruno Afonso, DUARTE Claudia Acosta

Dezmopatija kolateralnih ligamenata distalnih interfalangealnih veza (CL-DIPU) je od velikog značaja u sportskoj medicini konja. Međutim, faktori rizika u odnosu na razvoj ove dezmopatije nisu u potpunosti razjašnjeni. U literaturi, ono što je opisano u vezi sa ovim poremećajem, zasniva se na kliničkim posmatranjima kod životinja sa ovim promenama. Imajući u vidu navedeni scenario, cilj studije je bio da se verifikuju mogući spoljašnji i unutrašnji faktori rizika koji mogu da utiču na pojavu poremećaja kolateralni ligemanata distalnih interfalangealnih veza kod polo konja. U oglednoj grupi je bilo 25 konja iste uzgojne grupe koji su učestvovali u polo sportu. Sve su životi- 
nje pregledane ultrazvučnim aparatom. Ishod pregleda je bio definisan kao promena ehogenosti i/ili u odnosu na granične vrednosti CL-DIPU torakalnih ekstremiteta kod ispitivanih konja. Faktori koji su zavisli od samih životinja, bili su: starost, prisustvo angularnih devijacija i pol. Spoljašnji faktori koji su uzimani u obzir su bili u vezi sa upotrebom konja u sportske svrhe kao i način treninga kojem su konji podvrgavani u njihovoj profesionalnoj sportskoj karijeri. Verifikovana je povezanosti između faktora rizika $i$ ishoda. Rezultati ovih evaluacija su bili značajni onda kada interval pouzdanosti nije obuhvatao vrednost 1 . Pozitivna i značajna povezanost bila je uočena samo u odnosu na starost životinja. Korišćenje konja u odnosu na različite hendikepe nije imalo uticaja na pojavu poremećaja ligamenata. Ostali faktori koji su evaluirani, ukazali su na pozitivnu ali ne i zančajnu povezanost sa poremećajem. Zaključeno je da su životinje starije od devet godina u većem riziku u odnosu na CL-DIPJ poremećaj. 